\title{
Global Analysis of Potential COVID 19 Transmission and Ena- bling Factors
}

\author{
Hesham Magd ${ }^{1}$, Henry Karyamsetty ${ }^{2}$ \\ ${ }^{1}$ Quality Assurance and Accreditation, Faculty Head of Business and Economics, Modern College of Business \\ and Science, Muscat, Oman \\ 2 Department of Transportation, Logistics and Safety Management, Faculty of Business and Economics, Mod- \\ ern College of Business and Science, Muscat, Oman \\ *Correspondence: Hesham.Magd@mcbs.edu.om
}

How to cite this paper: Magd, H., \& Jonathan, H. (2021). Global Analysis of Potential COVID 19 Transmission and Enabling Factors. Global Journal of Epidemiology and Infectious Disease, 1(1), 46-61. Retrieved from https://www.scipublications.com/journal/index.php/gjeid/article/view/74

Received: July 10, 2021

Accepted: August 20, 2021

Published: August 21, 2021

Copyright: (c) 2021 by the authors. Submitted for possible open access publication under the terms and conditions of the Creative Commons Attribution (CC BY) license (http://creativecommons.org/licenses /by/4.0/).

\begin{abstract}
Background: Coronavirus disease has caused global turmoil especially causing huge impact on human life all over the world. Current reports states more than 3 million people have lost life and more than 160 million people are known to be suspected with the SARS-CoV-2. Transmission and disease incidence rates are indicators to assess the seriousness of COVID-19 pandemic and studies to understand the factors that aid in this direction are very vital to curb the disease. Methods: The study intends to discover the relationship by performing statistical analysis using correlation and multiple linear regression analysis between the variable's population density, temperature, relative humidity, and active time of virus and find out the parameters that predict the cases reported per million population in 83 countries. Results: Analysis indicates active time of virus in days is very positively associated with the COVID -19 cases in all the countries $r=.604, p<.01$. Active time of virus shows strong negative correlation with temperature $r=-.930, p<.01$ revealing that rise in temperature will reduce the virus activity in the population. Together, these variables will account for $36.2 \%$ variance in the cases per million population with no significant prediction estimated from any factor. Conclusion: The study outcomes clearly state that population density alone is insufficient to estimate the extent of influence on COVID -19 cases as the number of persons living per sq. $\mathrm{km}$ of land is a dynamic quantity tend to fluctuate over time and space due to migration of population. In conjunction to the previous studies reported on the environmental and climatic factors influencing the cases reported, population dynamics does not show much significance on the disease spread and incidence. Contribution: The rise in confirmed cases and the high incidence rate reported in countries can be attributed to the active time of virus life expectancy as there is a positive correlation observed between the COVID-19 cases reported and the virus active time in the examined countries. Also, environment and climatic factors play a role in modulating the infection and transmission rate with less significant influence of population density on the COVID-19.
\end{abstract}

Keywords: Active Time, Life Expectancy, Density, Population, Transmission, Disease, Virus, Temperature

\section{Introduction}

The coronavirus disease is currently causing a great concern ever since the SARSCoV-2 spilled out from the city of Wuhan in December 2019. WHO statistics report as of $10^{\text {th }}$ May 2021, around 159 million confirmed cases resulting in more than 3.3 million deaths [1]. The highest number of fatalities are reported from USA, Brazil and India occupying the top positions globally, [2] even though the pandemic has affected every country and city around the world. The official figures on COVID-19 reveal an alarming situation where the total cases in USA, Brazil, and India accounts to $10.06 \%, 7.10 \%$ and $1.62 \%$ of their total population respectively which together account for half of the global cases. On 
the other hand, the consequences of the pandemic have caused serious implications on mental health in young and old age group because of continuous staying away from social interactions due to lockdown and movement restrictions. Notwithstanding to say, the pandemic has impacted all matters of the world currently and recovering back to normalcy seems far from reality. Such a situation is also partly because of the growing globalization and increasing international trade which can rapidly spread the infectious diseases like COVID-19 [3].

Currently as the COVID-19 cases are increasing at an alarming rate, reducing the spread of infection from various modes is very much crucial to essentially control the incidence rate. At this juncture, studying the viability and stability of the virus to sustain in diverse physiological and environmental conditions will necessarily provide clues on the transmission phenomena. There are many previous studies reported by researchers investigating the factors influencing the COVID -19 incidence rates. Studies by Chan et al. [4] states that SARS-CoV-2 has different viability durations depending on the $\mathrm{pH}$ levels while the virus is very effectively transmitted through airborne medium in both outdoor and indoor environments [5]. According to study by Alam [6] reveals countries having high population density are more prone to transmit airborne infectious disease as observed in case of Bangladesh. Moreover, urbanization and migration of population from rural to cities adds significance to the existing problem. While Wong and Li [7] also report from their observations that population density has substantial contribution in disease transmission and spread within communities.

Extensive research on COVID -19 disease transmission gained importance subsequently to investigate the factors and determine the role of various parameters that influence the incidence rate and infection spread. Various researchers Yao et al. [5], Azuma et al. Babu et al. Coccia, Ma et al. Ogen, Zhu et al. Zoran et al. Domingo et al. [8-15] have tried to examine environmental parameters such as particulate matter, carbon monoxide, ozone, and oxides of nitrogen in the air having association with the disease transmission and incidence rates in different countries. While Abed and Lashin [16] explains from their investigation that population density and air pollution are the principle driving forces known to cause infection spread. In addition, meteorological and climatic factors such as temperature, relative humidity, precipitation, wind speed etc. are examined by various researchers Makama and Lim, Yang et al. Rosario et al. Qi et al. Pani et al. Guo et al. He at al. [17-23] reported varying level of influence on disease transmission and incidence in different countries that are investigated.

Kursheed et al. 2021 [24] States that environmental conditions such as temperature and ambient factors have role in transmission and infection spread. In this perspective, the role of various factors in understanding the transmission and infection spread of SARS-CoV-2 is very critical to sustain measures to contain the incidence rate, hence the authors would like to precisely examine the role of population density and virus life expectancy and understand the significance of these parameters apart from other factors in predicting the confirmed cases in different countries.

\section{Research Methods}

The main objective of the study is to define the role of the parameter's population density, temperature, relative humidity, and active time and to identify the predictor variable for cases per million population. The information comprising the population density, temperature, relative humidity, cases per million population and active time are collected for 83 countries spanning different geographical locations (Table 1). 
Table 1. Countries from different geographical regions considered for the study.

\begin{tabular}{|c|c|c|}
\hline Regions & Parameter studied & Countries/cities \\
\hline $\begin{array}{l}\text { Asia, Africa, Eu- } \\
\text { rope, North Amer- } \\
\text { ica, South America, } \\
\text { Central America, } \\
\text { Caribbean, Oceania }\end{array}$ & $\begin{array}{l}\text { Population density } \\
\text { Cases per million } \\
\text { population } \\
\text { Temperature } \\
\text { Relative humidity } \\
\text { Active time }\end{array}$ & $\begin{array}{l}\text { Uganda, Burundi, Chad, Rwanda, Romania, Algeria, Uzbekistan, } \\
\text { Kenya, Poland, Madagascar, Mali, Mozambique, Afghanistan, Benin, Si- } \\
\text { erra Leone, Serbia, Nicaragua, Guatemala, Croatia, Indonesia, El Sal- } \\
\text { vador, Germany, Burkina Faso, Bangladesh, Hungary, Central African } \\
\text { Republic, Bulgaria, Senegal, Vietnam, Cuba, Norway, Lithuania, Neth- } \\
\text { erlands, Jamaica, Ukraine, Austria, Zambia, Togo, Pakistan, Philippines, } \\
\text { Azerbaijan, Denmark, Finland, Honduras, Nigeria, Ghana, Haiti, Ka- } \\
\text { zakhstan, Somalia, Ireland, Tunisia, Georgia, Belarus, Costa Rica, Ecua- } \\
\text { dor, Mauritania, Egypt, Switzerland, Liberia, Morocco, Guinea Bissau, } \\
\text { Cameroon, Thailand, France, Spain, Italy, Belgium, Latvia, Lebanon, } \\
\text { Malaysia, Gabon, Greece, United Kingdom, Trinidad and Tobago, An- } \\
\text { gola, Libya, Portugal, Venezuela, Paraguay, Colombia, Argentina, Mex- } \\
\text { ico, Canada. }\end{array}$ \\
\hline
\end{tabular}

To achieve the study objectives, the researchers decided to utilize content analysis method to collect primary data related to COVID 19 from 83 countries. Content analysis is a popular method of data analysis that supports building theoretical framework. Content analysis is viewed simply as a systematic tool that examines communicated texts, current and historical data, and presented graphs either in hard or electronic format (Eriyanto, 2011, cited in [25] The purpose of content analysis to reduce the volume and the complexity of the available data and enable the researcher to identify themes, elicit an understanding, and draw valuable conclusions from the presented data [26,27].

The required data for all the above parameters are collected for the month of August 2020. Information on country population, population density is collected from [28] for all the countries and the COVID-19 cases per million population are taken from [29]. The information on temperature and relative humidity are gathered referring to $[30,31]$. To understand the parameter units, population density refers to the number of persons living per sq. $\mathrm{km}$ of land area while relative humidity is denoted in percent (\%), temperature in degree Celsius.

\subsection{Statistical analysis}

Descriptive analysis for the data variables was computed using NCSS data analysis software version 2021 and details are presented in Table 2. The quantitative data was analysed to calculate the mean, standard deviation, standard error, minimum and maximum values, variance and range for all the parameters and are presented in Table 3. Correlation tests and linear regression analysis to know the relationship between the variables was performed using SPSS statistical software version 26 and scatter plot diagrams for estimating the regression line graph was done with NCSS software. Spearman correlation analysis was performed to test the correlation coefficient between the variables and the association are tested for significance at .01 and .05 level. Linear regression analysis to determine the predictor variables for cases per million population was performed using NCSS data analysis software.

\section{Results}

The parameters that were examined in this study are number of cities, population density, temperature, relative humidity, activation time in days and minutes and cases reported per million population during April to July and August 2020. Population density refers to the number of persons living per square kilometer of the total geographical area of a country. Activation time in day/minutes indicate the SARS-CoV-2 life expectancy period that might have a significant impact on the incidence rate was also investigated. The 
data related to these parameters were collected from 83 different countries globally during the two different periods to understand the extent of relationship and the influence on the cases per million population (Table 1).

\subsection{Descriptive statistics}

From the data set comprising of 83 countries, the total number of cities account to 400 with an average of $4.81 \pm 6.75(\mathrm{n}=83)$ with a minimum of 1 and maximum of 38 cities. The mean population density for the data set shows $137.10 \pm 166.84,(\mathrm{n}=83)$ persons living per sq. $\mathrm{km}$. The minimum population density is 4 person per sq. $\mathrm{km}$ which was observed in Canada and Libya while the maximum was found in Bangladesh. The mean temperature recorded shows $22.59{ }^{\circ} \mathrm{C} \pm 5.11{ }^{\circ} \mathrm{C}(\mathrm{n}=83)$ with a minimum temperature of $12.7^{\circ} \mathrm{C}$ and maximum of $31.7^{\circ} \mathrm{C}$ in the data set. The mean relative humidity is observed to be $70.68 \pm$ $10.04 \%(n=83)$ with lowest of $41 \%$ and highest of $88 \%$. The activation time denoting the virus life expectancy in days shows a mean of $7.35 \pm 5.08$ days $(n=83)$, with minimum of 1.64 days and maximum of 18.71 days of activation duration. The mean number of cases reported per million population during April to July and August was $960.80 \pm 1132.13$ $(\mathrm{n}=83)$ and $1807 \pm 1918.82(\mathrm{n}=83)$ respectively. The minimum and maximum cases reported during April to July are 0 and 6531 while the minimum and maximum in August were 8 and 7250 respectively (Table 2 ).

Table 2. Descriptive details of the parameters studied in the data set countries.

\begin{tabular}{cccccc}
\hline Descriptive data & $\begin{array}{c}\text { Population } \\
\text { density }\end{array}$ & $\begin{array}{c}\text { Temperature } \\
\left({ }^{\circ} \mathrm{C}\right)\end{array}$ & $\begin{array}{c}\text { Variables } \\
\text { Cases/million pop- } \\
\text { ulation (August) }\end{array}$ & $\begin{array}{c}\text { Relative hu- } \\
\text { midity (\%) }\end{array}$ & $\begin{array}{c}\text { Activation time } \\
\text { (days) }\end{array}$ \\
\hline Mean & 137.10 & 22.59 & 1807.50 & 70.68 & 7.35 \\
$\begin{array}{c}\text { Standard devia- } \\
\text { tion }\end{array}$ & 166.84 & 5.11 & 1918.92 & 10.04 & 5.08 \\
Minimum & 4 & 12.7 & 8 & & \\
Maximum & 1127 & 31.7 & 7250 & 81 & 1.64 \\
Variance & 27836.34 & 26.18 & 3682268 & 100.88 & 25.88 \\
Standard error & 18.31 & 0.56 & 210.62 & 1.10 & 0.55 \\
Range & 1123 & 19 & 7242 & 47 & 17.07 \\
Count $(\mathrm{n})$ & & & 83 & & \\
\hline
\end{tabular}

\subsection{Comparative analysis}

Comparative analysis of the parameters between the variables of study were examined with reference to the cases reported per million population in the data set countries. Population density of the data set countries is taken as standard variable to observe the trend with cases per million population in both the periods and the activation time in days. For the comparative analysis, population density of countries was grouped into 4 ranges, the lowest population density was 4 persons per sq. $\mathrm{km}$ and the highest was 1127 persons per sq. km.

Countries in the population density range of 0 to 100 person per sq. $\mathrm{km}$ the mean cases reported per million population in August was $1841.51 \pm 2056.27(\mathrm{n}=47)$, with minimum of 45 and maximum of 7250 cases per million population. While during April to July the mean cases were $1058.6 \pm 1234.1$ with minimum of 0 and maximum of 6531 cases per million population. The mean activation time was $8.26 \pm 5.34$ with minimum of 1.64 and maximum of 18.71 days of virus life expectancy. The mean cases per million population reported in countries with population density between 100 to 200 persons per sq. km was $1758.2 \pm 1680.9(\mathrm{n}=19)$ having minimum of 27 and maximum of 5106 cases in August while during April to July was $852.8 \pm 834.8$ having minimum of 8 and maximum of 2877 
cases. The mean activation time was $6.23 \pm 4.30$ having minimum of 2 and maximum of 14.95 days of virus expectancy.

In the population density ranging from 200 to 300 persons per sq. $\mathrm{km}$ the mean cases reported per million population in August was $1933.4 \pm 1935.4(\mathrm{n}=9)$ with minimum of 8 and maximum of 4563 cases and during April to July the mean was $805.4 \pm 900.5$ having minimum of 0 and maximum of 2825 cases. The mean activation time was $6.79 \pm 5.40$ having a minimum of 1.9 and maximum of 13.7 days of expectancy observed in the density range. The mean cases per million population countries having population density between 300 to 400 persons per sq. $\mathrm{km}$ was $3417.6 \pm 2593.9(\mathrm{n}=3)$ having minimum of 1090 and maximum of 6214 cases in August and during April to July was 1438.6 \pm 576.2 having minimum of 487 and maximum of 2212 cases. The mean activation time was $5.63 \pm 5.80$ with minimum of 1.8 and maximum of 12.3 days. In the population density between 400 to 500 persons per sq. $\mathrm{km}$, the mean cases were $1341.3 \pm 1746.6(\mathrm{n}=3)$ having minimum of 34 and maximum of 3325 cases in August while during April to July, was $657.3 \pm 664.7$ with minimum of 22 and maximum of 1348 cases, while the mean activation time was 6.73 \pm 5.38 with minimum of 2.3 and maximum of 12.75 days of virus expectancy. Lastly countries having population density above 500 persons per sq. $\mathrm{km}$, the mean cases were 836.6 $\pm 676.5(\mathrm{n}=3)$ having minimum of 163 and maximum of 1516 cases in August and during April to July the mean cases was $514.6 \pm 572.6$ having minimum of 100 and maximum 116 cases. The mean activation time were $4.23 \pm 2.64$ with minimum of 1.7 and maximum of 6.98 days of virus expectancy in the density range (Table 3 ).

Table 3. Descriptive statistics of the parameters at different population density ranges in the data set countries.

\begin{tabular}{|c|c|c|c|c|c|}
\hline $\begin{array}{l}\text { Density range } \\
\text { (persons/sq. km) }\end{array}$ & $\begin{array}{l}\text { Descriptive } \\
\text { data }\end{array}$ & Count & $\begin{array}{l}\text { Population den- } \\
\text { sity }\end{array}$ & $\begin{array}{c}\text { Cases/million popula- } \\
\text { tion }\end{array}$ & Active time (days) \\
\hline \multirow{4}{*}{0 to 100} & Mean & \multirow{4}{*}{47} & 49.02 & 1841.51 & 8.26 \\
\hline & S. D & & 29.18 & 2056.26 & 5.34 \\
\hline & Minimum & & 4.0 & 45.0 & 1.64 \\
\hline & Maximum & & 99.0 & 7250 & 18.71 \\
\hline \multirow{4}{*}{101 to 200} & Mean & \multirow{4}{*}{19} & 130.1 & 1758.2 & 6.23 \\
\hline & S. D & & 29.8 & 1680.9 & 4.30 \\
\hline & Minimum & & 101 & 27 & 2 \\
\hline & Maximum & & 200 & 5106 & 14.95 \\
\hline \multirow{4}{*}{201 to 300} & Mean & \multirow{4}{*}{9} & 249.2 & 1933.4 & 6.79 \\
\hline & S. D & & 33.15 & 1935.4 & 5.40 \\
\hline & Minimum & & 200 & 8 & 1.9 \\
\hline & Maximum & & 296 & 4563 & 13.7 \\
\hline \multirow{4}{*}{$\begin{array}{l}301 \text { above up to } \\
1200\end{array}$} & Mean & \multirow{4}{*}{9} & 506.6 & 1865.2 & 5.54 \\
\hline & S. D & & 256.6 & 1990.6 & 4.31 \\
\hline & Minimum & & 310 & 34 & 1.7 \\
\hline & Maximum & & 1127 & 6214 & 12.75 \\
\hline
\end{tabular}

Analysis between number of cities and the population density indicates no direct proportional relation to each other as countries with a greater number of cities does not have high population density and vice versa. It is observed that the countries having high cases per million population during both the periods are not in the range of high population density. 


\subsection{Statistical analysis}

The statistical analysis to determine the relationship among population density, active time and cases reported per million population in 4 specific density ranges are computed with Spearman correlation and scatter plots to determine the regression pattern. Countries having population density in the range of 0 to 100 persons per sq.km show negligible positive correlation $r=.036, p=.808, \mathrm{n}=47$ with cases per million population indicating no significant relationship is observed to be found between the variables in the specific density range (see Figure 1), while the relation between active time of countries in the density range show moderate positive correlation with cases per million population $r=.596, p<.01, \mathrm{n}=47$ revealing an increase in active time in days will significantly affect the rise in cases within the density range countries (see Figure 2).

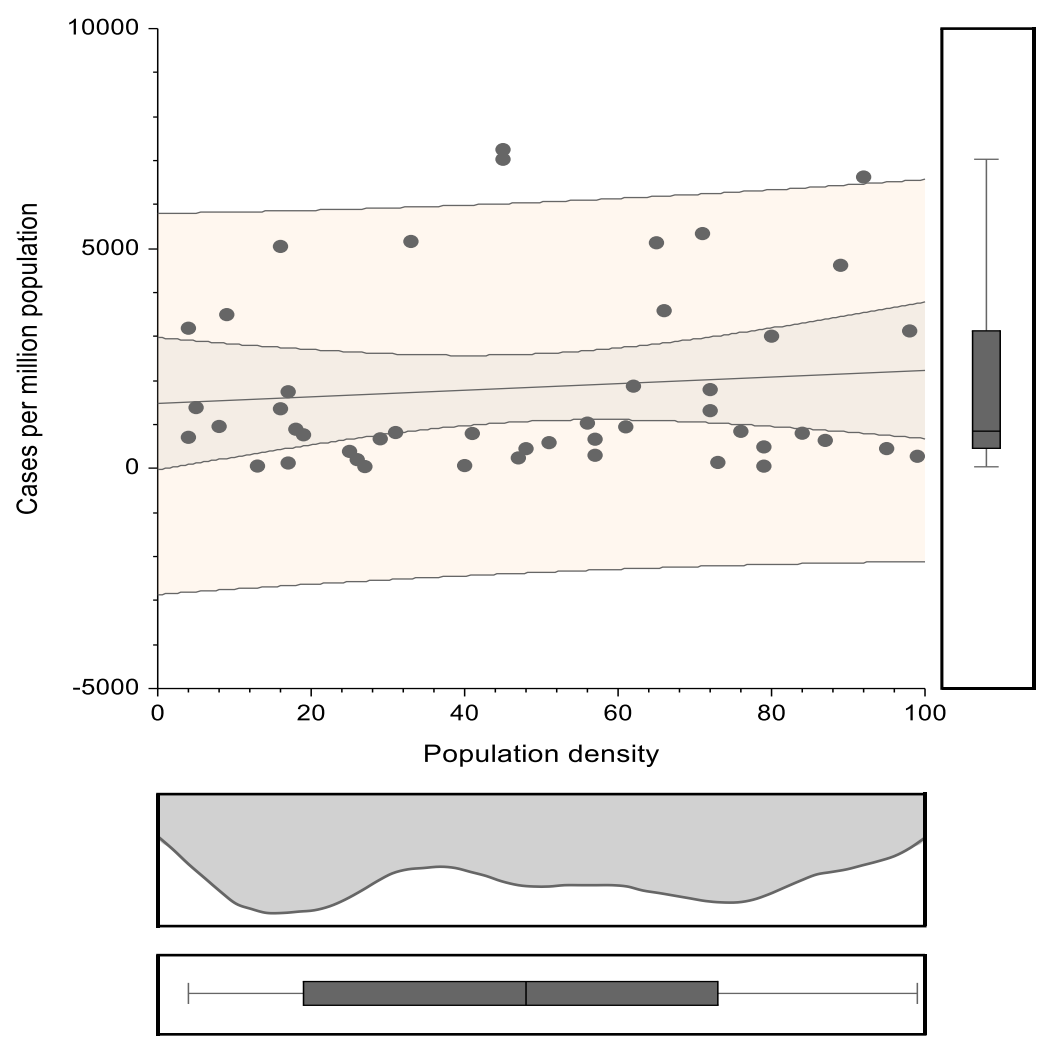

Figure 1. Relationship of cases reported per million population with population density at 0 to 100 density range.

Countries having population density in the density range of 101 to 200 persons per sq. $\mathrm{km}$ show very weak negative agreement with cases per million population $r=-.182, p$ $=.962, \mathrm{n}=19$, indicating non-significant association between the two variables while the correlation of active time of countries in the density range reveals strong positive agreement with cases per million population $r=.653, p=.002, \mathrm{n}=19$ indicating the significant correlation between the variable at $\alpha .01$ level (see Figure 3). Correlation between the population density and cases per million population in 201 to 300 persons per sq. $\mathrm{km}$ shows moderate negative disagreement $r=-.417, p=.181, \mathrm{n}=9$ while the association of active time with cases per million population reveals very high positive correlation $r=.962, p<.01$, $\mathrm{n}=9$ indicating a significant relationship between the variables at $\alpha .01$ level (see Figure 4). Relationship among population density and cases reported per million population in countries having above 300 up to 1200 persons per sq. $\mathrm{km}$ reveal moderate negative disagreement between them $r=-.467, p=.205, \mathrm{n}=9$ indicating no signification relationship in these variables, whereas the association of active time with confirmed cases shows weak 
positive disagreement $r=.200, p=.606, \mathrm{n}=9$ indicating no significant linear correlation occurs between active time and cases per million population tested in the density range (see Figure 5).

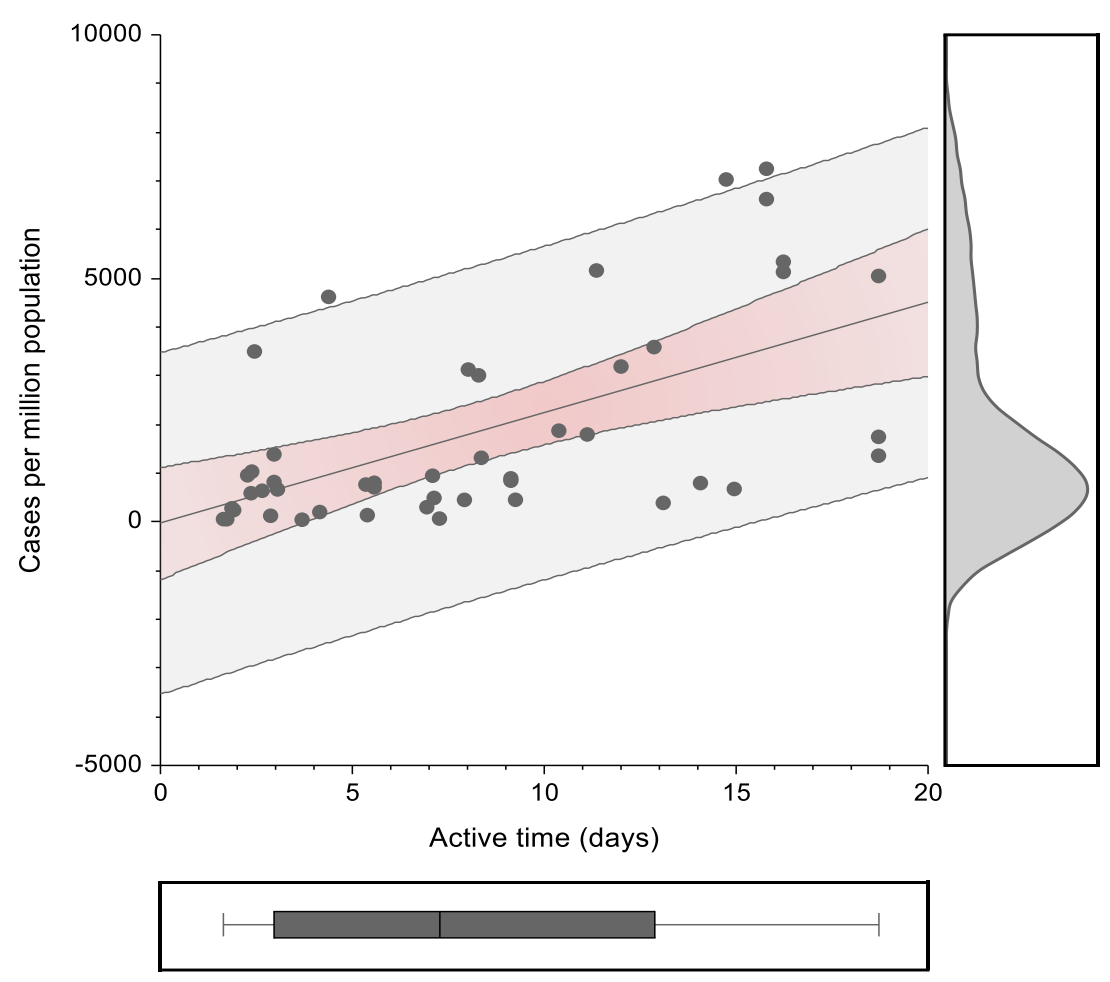

Figure 2. Relationship of cases reported per million population with active time (days) at 0 to 100 density range

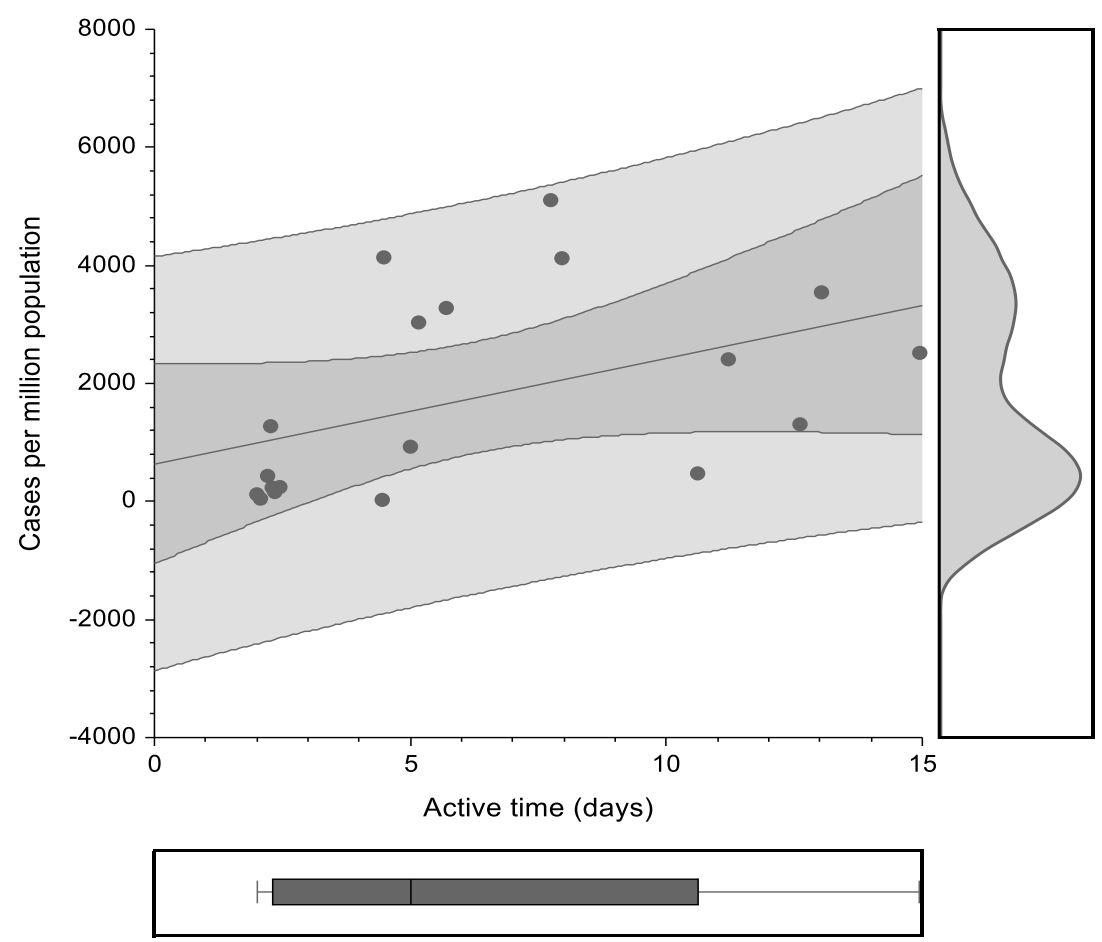

Figure 3. Relationship of cases reported per million population with active time (days) at 101 to 200 density range 


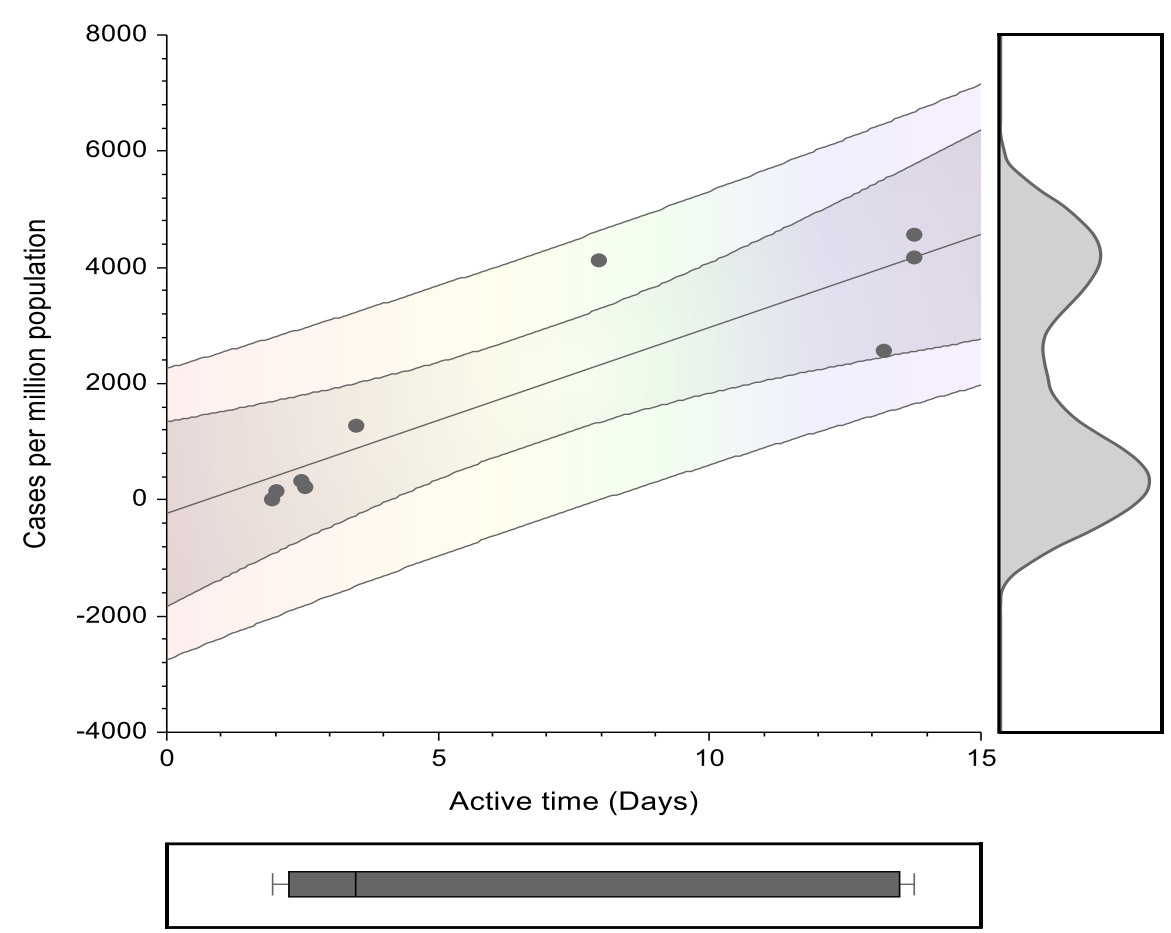

Figure 4. Relationship of cases reported per million population with active time (days) at 201 to 300 density range.

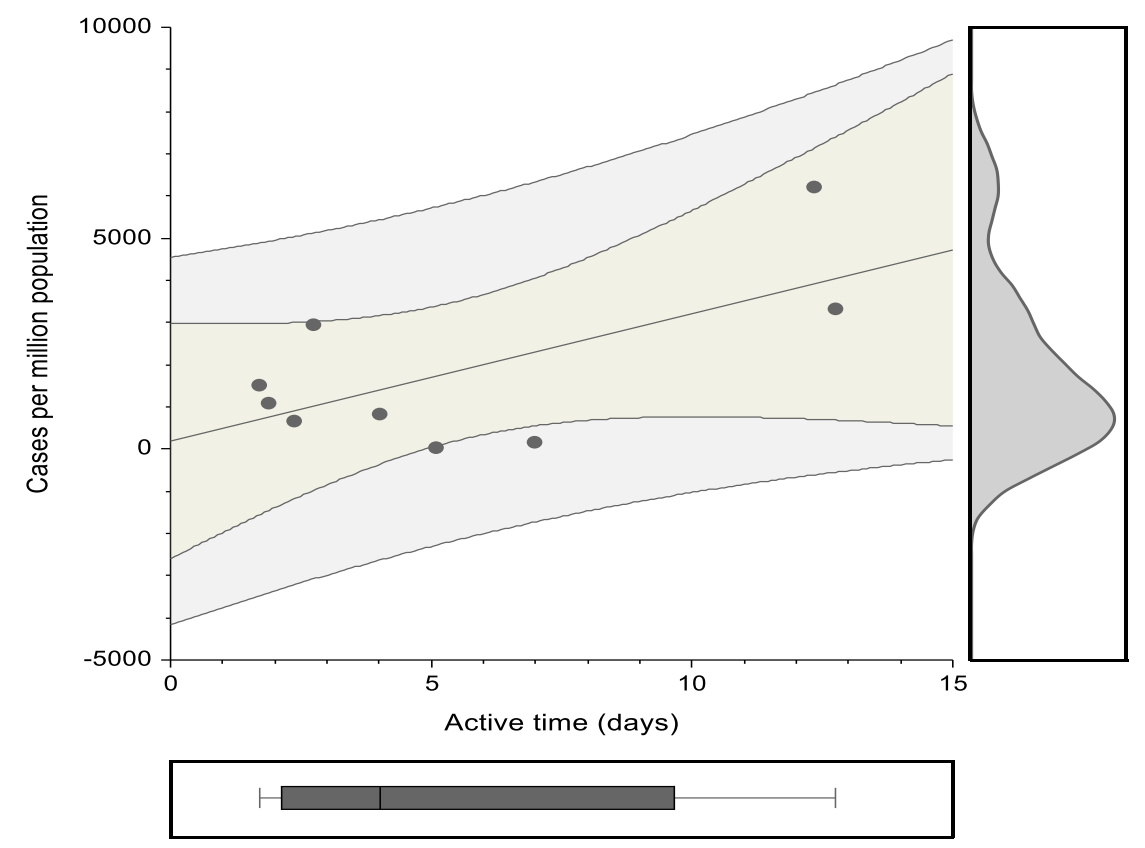

Figure 5. Relationship of cases reported per million population with active time (days) above 300 up to 1200 range.

Statistical analysis was performed to test the relationship between the variables and understand the factors that closely influence the cases reported per million population. Spearman correction test was performed to know the degree of association and whether the relationship is significant with the population density, temperature, relative humidity, activation time (days) and the cases per million population observed in August 2020 (Table 4). 
Table 4. Summary of descriptive and correlation matrix pair wise among the variables of the study.

\begin{tabular}{cccccccc}
\hline & Mean & S. D & $\begin{array}{c}\text { Cases/mil- } \\
\text { lion popu- } \\
\text { lation }\end{array}$ & $\begin{array}{c}\text { Popula- } \\
\text { tion den- } \\
\text { sity }\end{array}$ & $\begin{array}{c}\text { Tempera- } \\
\text { ture }\end{array}$ & $\begin{array}{c}\text { Relative } \\
\text { humidity }\end{array}$ & $\begin{array}{c}\text { Activation } \\
\text { time }\end{array}$ \\
\hline Cases/million pop- & 1807.5 & 1918.92 & 1.000 & & & & \\
$\quad$ ulation & 0 & & & & & & \\
Population density & 137.10 & 166.84 & -.026 & 1.000 & & & \\
Temperature & 22.59 & 5.11 & -.558 & .178 & 1.000 & & \\
Relative humidity $^{1}$ & 70.68 & 10.04 & -.229 & .119 & .122 & 1.000 & \\
Activation time $^{2}$ & 7.35 & 5.08 & .604 & -.211 & -.930 & -.436 & 1.000 \\
\hline
\end{tabular}

Significant at $\alpha .01$ and .05 level.

Spearman correlation between the population density and cases reported per million population shows negligible negative association $r=-.026, p=.812, \mathrm{n}=83$ indicating no significant relation exists between the density of persons per sq. $\mathrm{km}$ with the number of cases in the data set countries (see Figure 6). Correlation among temperature and cases per million population in August indicates moderate negative association $r=-.558, p<.01$, $\mathrm{n}=83$ with significant relationship at $\alpha .01$ level (see Figure 7).

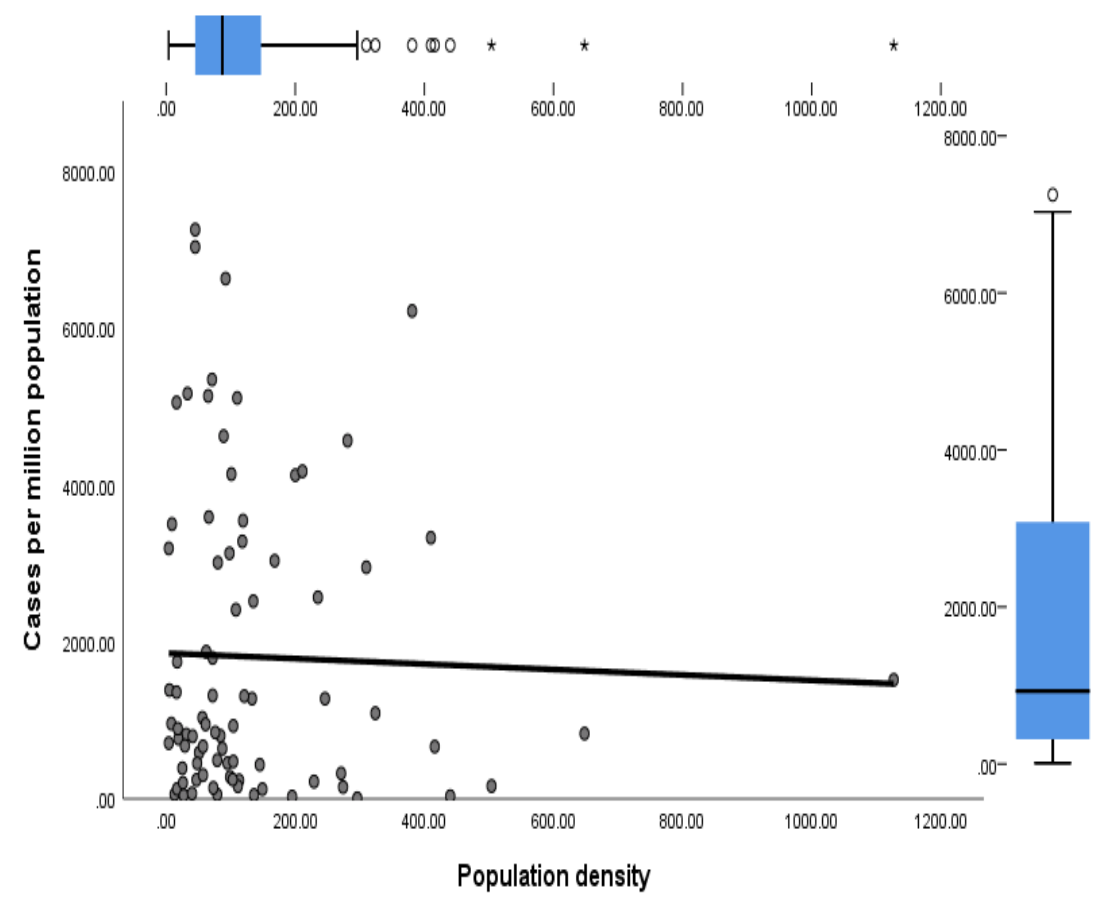

Figure 6. Scatter plot graph between population density and cases per million population reported in August 2020.

${ }^{1}$ Person/sq.km

${ }^{2}$ Virus life expectancy in days 


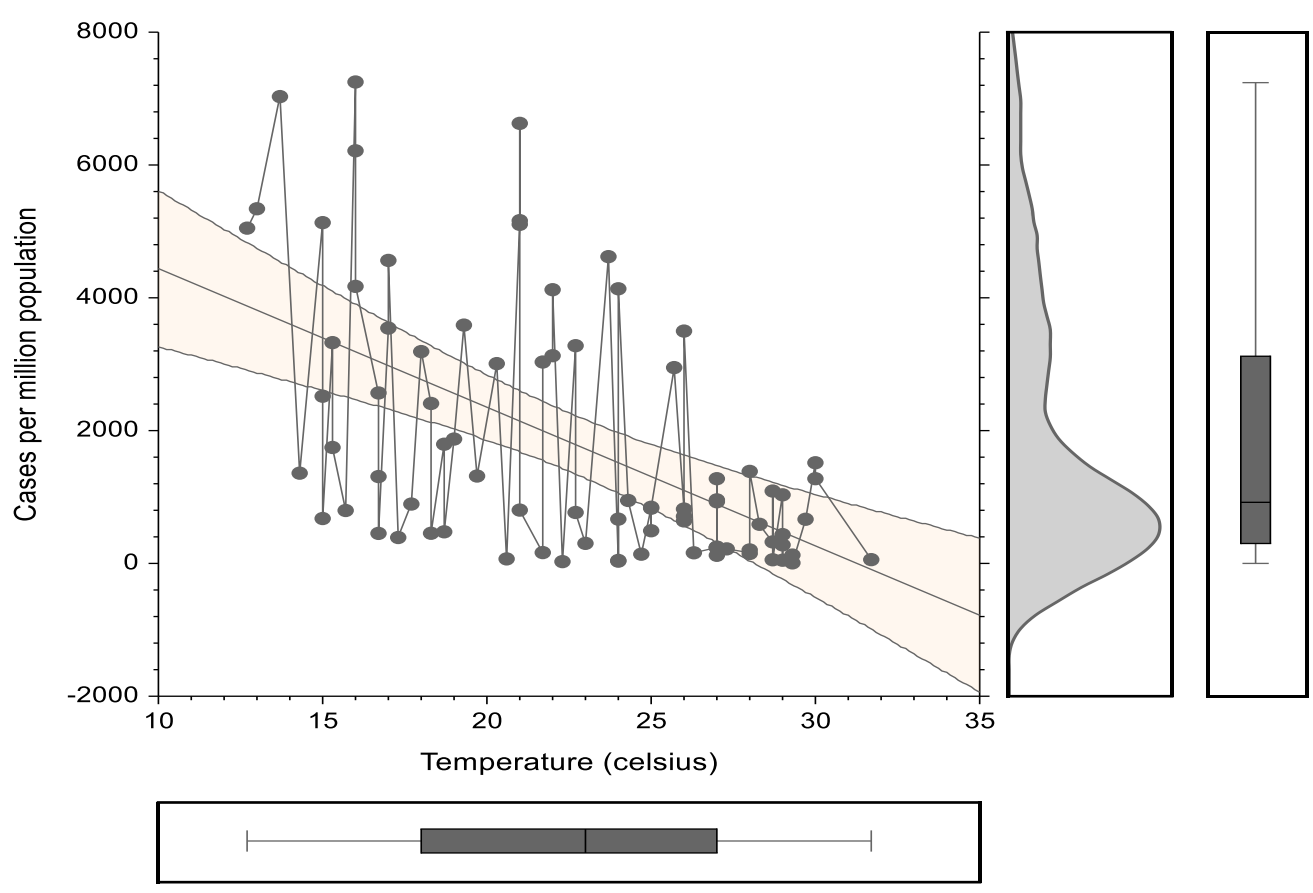

Figure 7. Regression analysis plot of temperature and cases per million population reported in August 2020.

Relative humidity shows weak negative correlation with cases per million population $r=-.229, p=.038, \mathrm{n}=83$ indicating significant relationship at $\alpha .05$ level which reveals that with increase in relative humidity there is drop in cases reported per million population as observed in the data set countries (see Figure 8). While the correlation between activation time and cases per million population shows strong positive association $r=.604$, $p<.01, \mathrm{n}=83$ implying a considerable increase in the virus life expectancy denoted by active time of pathogen will cause significant increase in cases per million (see Figure 9).

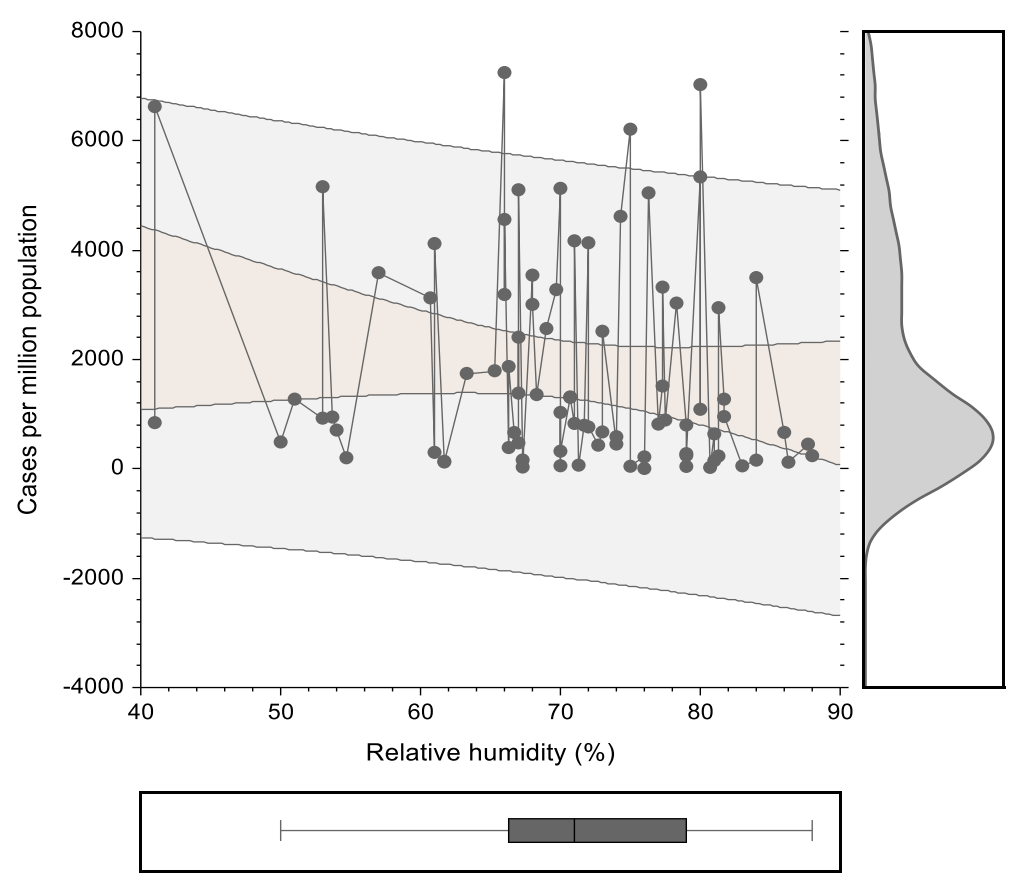

Figure 8. Regression analysis plot of relative humidity and cases per million population reported in August 2020. 


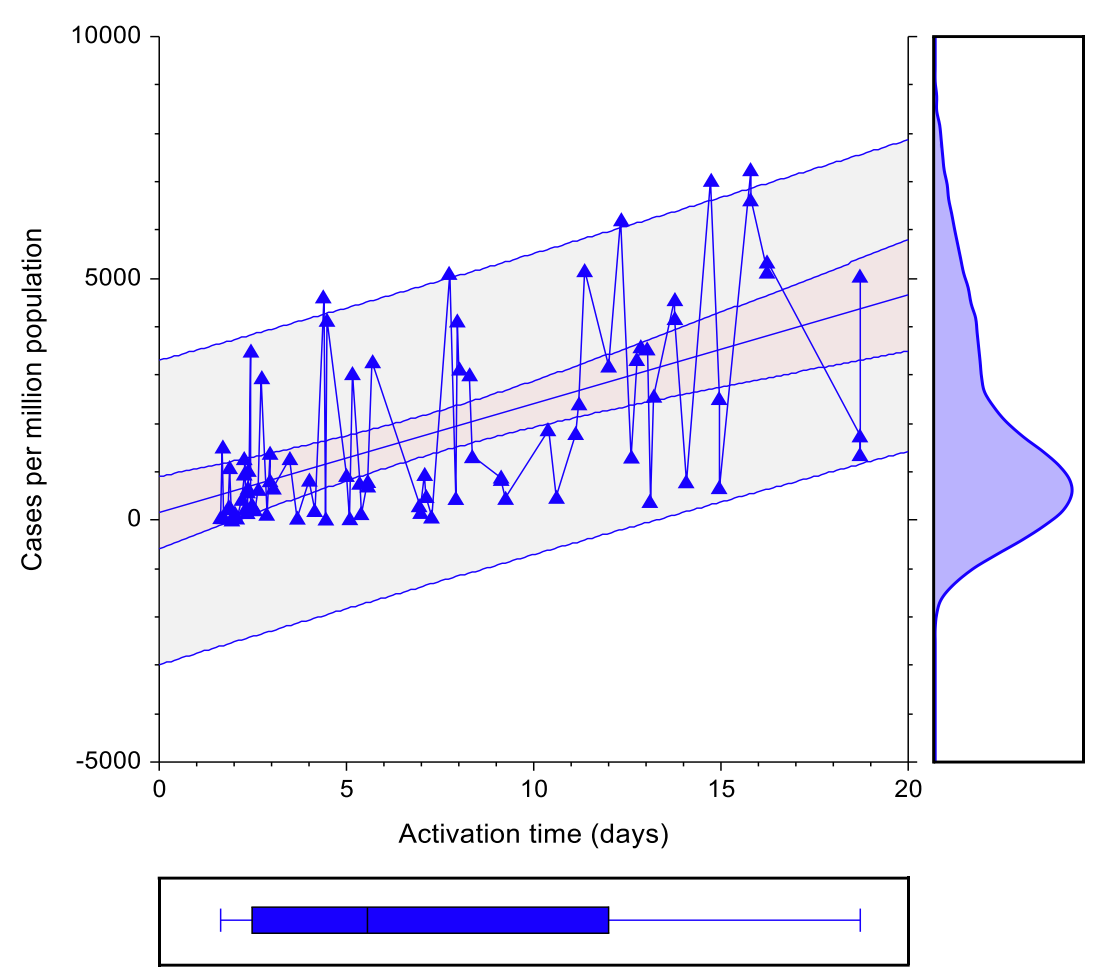

Figure 9. Regression analysis plot of active time in days and cases per million population reported in August 2020.

Further analyzing the association among predictor variable, the results show high negative correlation between temperature and activation time $r=-.930, p<.01, \mathrm{n}=83 \mathrm{im}$ plying a significant increase in ambient temperature will affect in reducing the virus life expectancy and vice versa (see Figure 10). Activation time and relative humidity shows medium to moderate negative correlation $r=-.436, p<.01, \mathrm{n}=83$ indicating a significant variation in relative humidity will result in effecting the virus life expectancy (see Figure $11)$.

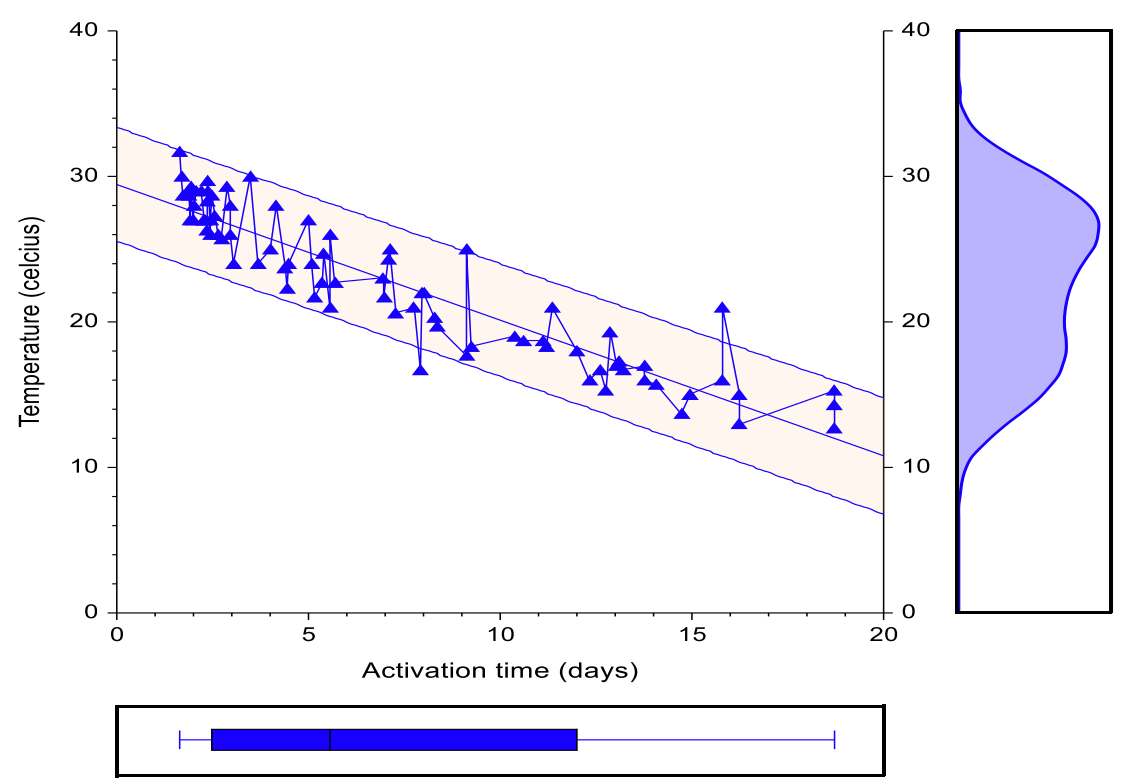

Figure 10. Regression analysis plot of active time and temperature in data set countries reported in August 2020. 


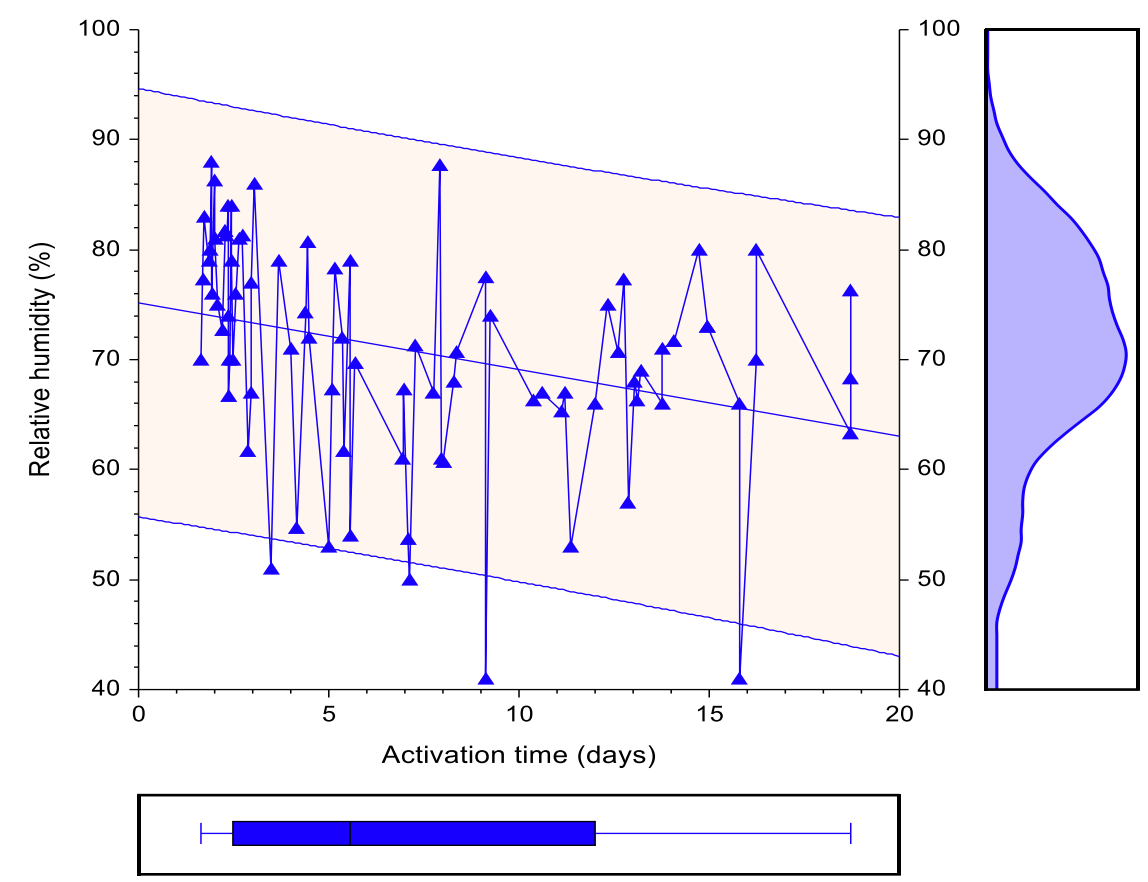

Figure 11. Regression analysis plot of active time and relative humidity in data set countries reported in August 2020.

Linear regression analysis was performed to know the variables that predict confirmed cases per million population in the data set countries. The results show $36.2 \%$ of variance in the cases per million population are influenced by population density, temperature, relative humidity, and activation time $F(4,78)=11.08, p<.01, R^{2}=.362$. Analysis of individual predictors reveals that population density $(\beta=.093, t=.998, \mathrm{p}=.321)$, temperature $(\beta=-.019, t=-.058, \mathrm{p}=.954)$, relative humidity $(\beta=.013, t=.102, \mathrm{p}=.919)$ and activation time $(\beta=.600, t=1.754, \mathrm{p}=.083)$ all does not significantly predict the cases reported per million population in the data set countries at $\alpha .05$ level. From the regression analysis it is inferred that among the variables that are considered, no parameter is observed to be closest predictor to influence the confirmed cases reported in the countries.

\section{Discussion}

This study explicitly looks at two primary parameters, the population density and active time represented as virus life expectancy along with the secondary parameters' temperature and relative humidity. These parameters are tested to know how they serve as factors determining the cases reported in the data set countries. Though there are studies done by various researchers considering these parameters, however there are no known reports found in the literature on using active time in terms of the virus life expectancy and its role on the confirmed cases of COVID-19 in any country. In this backdrop the result of this study perceives importance and provides worthful knowledge to the existing literature on COVID-19 pandemic.

The intensity of the disease caused by the SARS-CoV-2 all over the world are attributed to many factors, one predominant factor is the population density calculated as persons living per sq. km of the total land area of a country, though not to disregard country population and number of cities in each country. Examining the influence of population density on cases reported per million population during August in the countries of our subject (Table 1), our outcomes contradict with findings reported by, Kadi and Khelfaou, Pirouz et al. Ahmed et al. Jahangiri et al. [32-35] claiming that population den- 
sity effectively predicts disease spread. Remarkably, the density of people varies over period of time, depending on the migration pattern and movement between urban and rural, as positive cases of COVID -19 are not just confined to cities but has spread over to rural side.

Under the assumptions stated in literature, where population tends to be more concentrated in urban environments, the reports of confirmed cases normally should be high than rural communities, but such a trend is not observed in the current pandemic situation, thus justifying the explanation by. Hsu [36] studies under large scale prove that essential factors such as city size, socioeconomic conditions of people, health care provisions, extent of preventive measures like social distancing, use of personal hygiene etc. are very important factors that should be evaluated alongside the population density to assess the realistic effect on the COVID -19 transmission and spread.

Further, population density of countries examined even at different density ranges does not sufficiently prove to be significantly correlated with confirmed cases justifying that number of persons inhabiting in unit area categorically is not a good measure to gauge the disease incidence rate, which is consistent with the studies by Carozzi et al. Hamidi et al. $[37,38]$ however to some extent, population density depending on the nature of other parameters can associate with COVID -19 to moderate extent [39].

Our results indicate active time which represents the virus life expectancy in the environments is known to show significant association with COVID-19 in overall analysis and, also at corresponding population density ranges. The minimum and maximum active time in days was observed in countries having a population density range of 0 to 100 persons per sq. $\mathrm{km}$ which correspondingly also reported the maximum cases per million population over other density ranges. To denote that temperature is central factor affecting the active time observed in the entire data set countries as our results show that with decrease in active time in days there is a corresponding increase in the temperature observed gradually from lower density to higher density range indicating a significant inverse relationship between both these parameters.

Referring to Table 3 , at the average highest temperature of $24.0^{\circ} \mathrm{C}$, the average active time 12.75 in days is found to be lowest while at the average lowest temperature of 21.9 ${ }^{\circ} \mathrm{C}$, the average time 18.75 is found to be the highest. From this justification we can say that temperature and active time denoting the virus life expectancy are focal points. In Addition, one interesting conclusion that can be drawn from the observations in Table 3 with increase in average population density across the different density ranges, the average active time of virus expectancy tends to decrease contradicting the presumptions surrounding the role of population density on COVID -19 cases.

In conclusion, the results confirm that active time representing the virus life expectancy in days correspondingly influences the cases per million population reported in August 2020 as well has high significant association with COVID -19 at all the 4 density ranges from the observations in Table 4. From the parameters examined in the study, we can clearly denote that active time is a very close associate variable next to ambient temperature in determining the fluctuations in the COVID-19 in terms of assessing the number of cases per million population, however population density shows very rare relationship without any consistent influence on the disease incidence rate. In this backdrop, our results on temperature effect on active time and its subsequent influence on confirmed cases apparently agree with findings of $[9,40,41]$.

Disregarding, the obtained results show disagreements with the previous studies, the nature of countries chosen, data range and duration of observations would not be reasonable to generalize the outcomes of this study to other geographical locations. On the contrary it is also important to understand that with strict preventive measures which are enforced by all nations, such as social distancing, lockdowns, and prohibiting large gatherings can reduce the effect of high population density on COVID -19, in such a scenario, 
considering population density variable as factor to study the disease incidence rate becomes insignificant.

\section{Conclusion}

Coronavirus disease currently is gripping the entire world which led to a serious situation of despair. Ever since, the disease was first detected during the end of year 2019, the world has lost more than 3 million population. The present study attempts to understand the factors among population density, temperature, relative humidity and active time that closely influence the cases reported per million population due to transmission and spread of infection caused by the SARS-CoV-2 pathogen. The results of the analysis are subjected to observations recorded in the parameters during August 2020. The outcomes of the study spanning over 83 countries indicates that there is significant positive correlation between the cases reported per million population with active time of virus life expectancy in days whereas the temperature is known to have inverse relationship with the active time of virus, though no parameter examined in our study significantly predicts the cases per million population reported in the data set countries.

On the other hand, evidence from various literature shows density of population is a factor has affinity to determine the disease incidence rate, while our analysis demonstrates that with the increase in the average population density across the 4 density ranges, there is a drop observed in both the average and maximum active time of virus, as a result indicating that population density does not sufficiently prove as driving factor for the cases reported in the population. This is because population density is dynamic factor bound to fluctuate with standard of living, economic status, awareness on personal and community hygiene and, also the strict preventive measures enforced in different countries reduces the probability of transmission and spread from person to person. However, despite elaborate studies are done on factors such as meteorological, environment and climatic on COVID- 19 incidence rate, intricate studies are needed to confirm the role of population density and other parameters and to understand the extent of influence each parameter has on the COVID-19 transmission and spread of infection in different geographical settings.

Conflict of interest: The authors declare confirm that there is no conflict of interest arising with anyone with regard to the research article.

Funding information: The authors declare that there no financial support or funding availed from any internal or external organisation in conducting the research or in preparing the research article.

\section{References}

[1] World Health Organization. WHO coronavirus dashboard. https://covid19.who.int/- Accessed January 10, 2021.

[2] John Hopkins University. Coronavirus resource center. 2021; https://coronavirus.jhu.edu/data

[3] Wang L, Didelot X, Yang J. et al. Inference of person-to-person transmission of COVID-19 reveals hidden super-spreading events during the early outbreak phase. Nat. Commun. 2020; 11:5006.

[4] Chan KH, Sridhar S, Zhang RR, et al. Factors affecting stability and infectivity of SARS-CoV-2. Journal of Hospital Infection. 2020; 106(2):226-231.

[5] Yao M, Zhang L, Ma J, Zhou L. On airborne transmission and control of SARS- CoV-2. Science of the Total Environment. 2020; 731:139178.

[6] Alam, Z. Is Population Density a Risk Factor for Communicable Diseases Like COVID-19?- a Case of Bangladesh. Asia Pacific Journal of Public Health. 2021; 1-3.

[7] Wong DWS, Li Y. Spreading of COVID-19: Density matters. PLoS One. 2020; 15(12): e0242398.

[8] Azuma K, Kagi N, Kim H, Hayashi M. Impact of climate and ambient air pollution on the epidemic growth during COVID-19 outbreak in Japan. Environmental Res. 2020; 190: 110042.

[9] Babu SR, Rao NN, Kumar SV, Paul S, Pani SK. Plausible Role of Environmental Factors on COVID-19 Transmission 2 in the Megacity Delhi India. Aerosol Air Qual. Res. 2020; 20:2075-2084.

[10] Coccia M. Factors determining the diffusion of COVID-19 and suggested strategy to prevent future accelerated viral infectivity similar to COVID. Sci. Total Environ. 2020; 729: 138474. 
[11] Ma Y, Zhao Y, Liu J, He X, Wang B, Fu S, et al. Effects of temperature variation and humidity on the death of COVID-19 in Wuhan China. Sci. Total Environ. 2020; 724: 138226.

[12] Ogen $\mathrm{Y}$. Assessing nitrogen dioxide $\left(\mathrm{NO}_{2}\right)$ levels as a contributing factor to coronavirus (COVID-19) fatality. Sci. Total Environ. 2020; 726:138605.

[13] Zhu Y, Xie J, Huang F, Cao L. Association between short-term exposure to air pollution and COVID-19 infection: Evidence from China. Sci. Total Environ. 2020; 727: 138704.

[14] Zoran MA, Savastru RS, Savastru DM, Tautan MT. Assessing the relationship between surface levels of PM2.5 and PM10 particulate matter impact on COVID-19 in Milan, Italy. Sci. Total Environ. 2020; 783:139825.

[15] Domingo JL, Marques M, Rovira J. Influence of airborne transmission of SARS-CoV-2 on COVID-19 pandemic. A review. Environmental Res. 2020; 188: 109861.

[16] Abed K, Lashin MAA. An analytical study of the factors that influence COVID-19 spread. Saudi Journal of Biological Sciences. 2021; 28:1177-1195.

[17] Makama EK, Lim HS. Effects of location specific meteorological factors on COVID-19 daily infection in a tropical climate: A case of Kaula Lumpur Malaysia. Advances in Meteorology. 2021; 6675973.

[18] Yang XD, Li HL, Cao YE. Influence of Meteorological Factors on the COVID-19 Transmission with Season and Geographic Location. Int. J. Environ. Res. Public Health. 2021; 18:484.

[19] Rosario DKA, Mutz YS, Bernardes PC, Junior CAC. Relationship between COVID-19 and weather: Case study in a tropical country. Int. J. Hyg. Environ. Health. 2020; 229: 113587.

[20] Qi H, Xiao S, Shi R, Ward MP, Chen Y, Tu W. COVID-19 transmission in Mainland China is associated with temperature and humidity: A time-series analysis. Sci. Total Environ. 2020; 728:138778.

[21] Pani SK, Lin NH, Babu SR. Association of COVID-19 pandemic with meteorological parameters over Singapore. Sci. Total Environ. 2020; 740:140112.

[22] Guo C, Bo Y, Lin C, Li HB, Zeng Y, Zhang Y. Meteorological factors and COVID-19 incidence in 190 countries: An observational study. Sci Total Environ. 2021; 25:757:143783.

[23] He Z, Chin Y, Yu S, Huang J, Zhang CJP, Zhu K. The Influence of Average Temperature and Relative Humidity on New Cases of COVID-19: Time-Series Analysis JMIR Public Health Surveillance. 2021; 7(1).

[24] Khursheed A, Mustafa F, Akhtar A. Investigating the roles of meteorological factors in COVID-19 transmission in Northern Italy. Environ Sci Pollut Res. 2021.

[25] Gandasari D, Dwidienawati D. Content analysis of social and economic issues in Indonesia during the COVID-19 pandemic. Heliyon. 2020; 6:1-9.

[26] Bengtsson, M. How to plan and perform a qualitative study using content analysis. NursingPlus Open. 2016 ; 2: 8-14.

[27] Polit DF, Beck CT. (2006). Essentials of nursing research: Methods, appraisal, and utilization. Lippincott Williams \& Wilkins.

[28] World Population Review (2020). World population by country [Online]. Available at: https://worldpopulationreview.com/. Accessed August 22, 2020.

[29] Our World in Data (2020). Coronavirus pandemic (COVID -19) [Online]. Available at: https://ourworldindata.org/coronavirus. Accessed September 15, 2020.

[30] Weather Atlas (2020). Weather around the world [Online]. Available At: https://www.weather-atlas.com/en/countries Accessed August- September 2020.

[31] National Oceanic and Atmospheric Administration, https://www.ncdc.noaa.gov/climate-information/statistical-weather-andclimate-information. Accessed September 2020.

[32] Kadi N, Khelfaou M. Population density, a factor in the spread of COVID-19 in Algeria: statistic study. Bulletin of the National Research Centre. 2020; 44:138.

[33] Pirouz B, Haghshenas SS, Pirous B, Haghshenas SS, Piro P. Development of an Assessment Method for Investigating the Impact of Climate and Urban Parameters in Confirmed Cases of COVID-19: A New Challenge in Sustainable Development. Int. J. Environ, Res. Public Health. 2020; 17:2801.

[34] Ahmadi M, Sharifi A, Dorosti S, Ghoushchi SJ Ghanbari N. Investigation of effective climatology parameters on COVID-19 outbreak in Iran. Sci. Total Environ. 2020; 729: 138705.

[35] Jahangiri M, Jahangiri M, Najafgholipour M. The sensitivity and specificity analyses of ambient temperature and population size on the transmission rate of the novel coronavirus (COVID-19) in different provinces of Iran. Sci. Total Environ. 2020; 728:138872.

[36] Hsu J. "Population density does not doom cities to pandemic dangers: crowding connections, among communities and other factors seem to better explain infection and mortality rates". Scientific American. 2020.

[37] Carozzi F, Provenzano S, Roth S. 2020. Urban Density and COVID-19. IZA Discussion Papers 13440, Institute of Labor Economics (IZA).

[38] Hamidi S, Sabouri S, Ewing R. Does density aggravate the COVID-19 pandemic? Early findings and lessons for planners. Journal of the American Planning Association. 2020; 86:4: 495-509.

[39] Bhadra A, Mukherjee A, Sarkar K. Impact of population density on COVID-19 infected and mortality rate in India. Modeling Earth Systems and Environment. 2021; 7: 623-629.

[40] Kassem, AZE. Does temperature effect COVID-19 transmission? Frontiers in Public Health. 2020; 8. 
[41] Auler C, Cassaro FAM, da Silva VO, Pires LF. Evidence that high temperatures and intermediate relative humidity might favor the spread of COVID-19 in tropical climate: A case study for the most affected Brazilian cities. Sci. Total Environ. 2020; 729: 139090. 